\title{
Proximate composition and bioaccumulation of heavy metals in edible Achatina spp in some rural agro-settlements, south-east Nigeria
}

\author{
Emmanuel I. Nnamonu ${ }^{1 *} \mathbb{D}$, Gregory E. Odo², Ifeanyi O. Ajuzie² and Chritopher D. Nwani²
}

\begin{abstract}
Background: Animals that live and feed on the soil and its constituents and products naturally absorb heavy metals and pass to other organisms linked in the food chains. The present study was designed to examine bioaccumulation of heavy metals levels and proximate composition quality in edible Achatina spp sampled in agro-rural settlements, south-east Nigeria.

Results: The proximate composition recorded the presence of moisture, protein, crude fibre, fat and oil, ash, carbohydrates, nitrogen and calcium, which were similar across selected Achatina spp except for calcium, which was significantly higher in A. achatina. The bioaccumulation factors of heavy metal contents in snails were generally low (below recommended tolerable limits according to WHO standard).

Conclusion: The good number of nutrients recorded in proximate composition makes the Achatina spp an alternative to domestically farmed animals. Achatina achatina contained most calcium level compared with Achatina fulica and Achatina marginate. The bioaccumulation factors of heavy metal contents in snails were generally low (below recommended tolerable limits according to WHO standard). Land snails in our study areas were safe for consumption.
\end{abstract}

Keywords: Achatina spp, Proximate composition, Metals, South-east Nigeria

\section{Background}

The pollution hazards that result from the rapid trend of industrialisation globally have made every place and organisms including humans exposed to agents of pollution. Despite the fact that the current situation is as a result of man's quest for improved quality of life, agents of pollution emitted from industrial activities have become a major threat to all ecological systems, the earth as a whole and its structures. Human activities outweigh natural emissions with regard to release of agents of pollution into the environment, especially into the soil and water, thereby contaminating ecosystems in large parts of the world. Specifically, pesticides (mostly herbicides

\footnotetext{
*Correspondence: nnamonue@gmail.com

1 Department of Biology, Federal College of Education, Eha-Amufu,

Enugu State, Nigeria

Full list of author information is available at the end of the article
}

and insecticides) and other chemicals are commonly used for fishing and farming by most rural settlers without recourse to the effect on the ecotoxicology effects, especially to aquatic lives and the fitness of the surface water sources for human consumption and domestic uses (Nnamonu et al., 2018). Once emitted into the soil, they contribute to the deposition and build-up in soils. One of the most harmful groups emitted into the soil is the heavy metals because of their persistence ability. Animals (e.g. land snail) and plants that live and feed on the soil, its constituents and products, naturally absorb these heavy metals and pass to other organisms linked in the food chains. These metals are bioaccumulative in ecosystems, and levels of some of them can be biomagnified in predatory animals, especially fish (WHO, 2007).

Most times, some individuals tend to assume that places with little or no industry, especially rural settlements, should be free from the scourge of environmental 
pollution, but that assumption is wrong because longrange transboundary air pollution has been reported as the major source of exposure to heavy metals. This is as a result of the heavy metals persistence and potential for global atmospheric transfer, atmospheric emissions, which affect even the most remote regions of the world (WHO, 2007). Most heavy metals in the soil are deposited at the upper layer of the soil (CDC, 1991) making it easy to be absorbed to animals that burrow, feed and crow at that level of the soil, especially land snails.

Bioaccumulation of toxic heavy metals in the human body system is very dangerous to human health as it could cause damage to some of the visceral organs in the body that can lead to serious health problem (Rusan et al., 2007). The build-up of heavy metals in the body could lead to malfunctioning of the liver, kidneys and circulatory system. WHO (2007) reported that human exposure to heavy metals is associated with health problems such a kidney and bone damage, lung cancer, developmental and neurobehavioral effects on foetuses, infants and children, and elevate blood pressure in adults.

Despite the association between land snails and transmission of heavy metals into the food chain, land snails play unique roles in their ecosystem such as decomposition of litter, the concentration of soil calcium and also serve as an important food source for other animals (Lange \& Mwinzi, 2003). Snail meat has been widely accepted as an alternative source of protein in Nigeria, especially in the rural settlements where families consume it and also gather more for commercial purposes. This is because snail meat is found to be rich in protein, is low in lipid and contains essential minerals like zinc, iron, calcium and magnesium (Ademolu et al., 2004). The meat of snail is palatable, nutritious and rich in essential amino acids such as lysine, leucine, isoleucine and phenylalanine as well as high iron contents (Ebenebe, 2000). Similarly, snail shell is of economic importance. It serves as a source of calcium and phosphorous useful in formulating animal diets and for ornamental uses (Houndonougbo et al., 2012).

Molluscs, in particular, have shown considerable promise as biomonitors of such pollution (Whitfield, 2001). Therefore, the present study was designed to examine bioaccumulation of heavy metal levels and proximate composition quality in edible Achatina spp sampled in agro-rural settlements, south-east Nigeria.

\section{Methods}

\section{Study area}

The study was carried out at five communities in EhaAmufu, south-east Nigeria. Eha-Amufu is a town in south-eastern Nigeria. Coordinates - Universal Transverse Mercator (UTM): LN63; geographical coordinates in decimal degrees (WGS84): latitude: 6.667, longitude: 7.767; geographical coordinates in degrees minutes seconds (WGS84): latitude: $640^{\prime} 00^{\prime \prime}$, longitude: $746^{\prime} 00^{\prime \prime}$. Daylight: sunrise: 06:17:35; sunset: 18:08:08. It is located at latitude: $6^{\circ} 39^{\prime} 32.94^{\prime \prime} \mathrm{N}$; longitude: $7^{\circ} 45^{\prime} 34.60^{\prime \prime} \mathrm{E}$. It is situated at an elevation of $109 \mathrm{~m}$ above sea level (http://www.tageo.com/index-e-ni-v-00-d-m2792190. $\mathrm{htm})$. Eha-Amufu has an average temperature of $27.0{ }^{\circ} \mathrm{C}$ and an average precipitation of $1669 \mathrm{~mm}$ (CLIMATEDATA.ORG). It is traversed by the Ebonyi River (ER) and its tributaries. The residents are dominant of the Igbo speaking tribe and mainly rural farmers, fishermen, artisans and traders. Two distinct seasons occur in the area: the dry and wet seasons. The dry season stretches from November to April or May, while the rainy season begins around May and ends in October (Nnamonu et al., 2019).

\section{Quality assurance}

Glassware thoroughly washed with a solution of detergent and then rinsed with distilled water. They were later allowed to drain. A small quantity of concentrated HNO3 was introduced into the glassware and placed on the heating mantle. The fumes produced from the heating of the acid condensed on the walls of the glassware to destroy the organic contaminants. The glasswares were removed from the heating mantle and allowed to cool for some minutes and then rinsed with distilled demineralised water. The glasswares were later placed back on the heating mantle to dry.

The plastic used was soaked in $1 \mathrm{M}$ nitric acid overnight and washed with teepol, rinsed with tap water and finally with deionised water.

\section{Sample collection}

The snail sampling adopted a direct search technique, which lasted for six months. Identification of snails was carried out using a field guide to the land snail and slugs by Herbert and Kilburn (2004). Soil samples were collected at a distance of 3 to $5 \mathrm{~cm}$ into the soil in every sampling sight. A total of 270 big land snails (Achatina spps- A. achatina, A. marginata \& A. fulica) were used for this study.

\section{Sample preparation}

Uboh et al. (2014) was adopted with little alteration. Collected snail samples were dissected within $12 \mathrm{~h}$. of collection. Snails were killed by striking iron rod on their shells. Thereafter, their foot was gently separated and dried at $60{ }^{\circ} \mathrm{C}$ in an oven. Thereafter, whole body tissues were washed in distilled water and dried separately in oven at $60{ }^{\circ} \mathrm{C}$. The dried tissues were powdered and stored separately. 
Soil samples were collected from various locations of the reservoir and were sieved by using a sieve (mesh size $0.5 \mathrm{~mm}$ ), and the fine fractions obtained were air-dried. Air-dried samples were then ground, powdered and preserved in desiccators.

\section{Sample digestion}

The method of Association of Official Analytical Chemistry (1990) was followed. Samples of dried snail tissue were weighed $(1.5 \mathrm{~g})$ and then transferred into separate conical flask. Decomposition of the organic matter content of the sample was done following $\mathrm{HNO} 3-\mathrm{H} 2 \mathrm{SO} 4$ wet digestion method. Content of the conical flask was added $5 \mathrm{ml}$ of concentrated $\mathrm{HNO}_{3}$ followed by $10 \mathrm{ml}$ of concentrated $\mathrm{H}_{2} \mathrm{SO}_{4}$. Thereafter, it was placed on the heating mantle at a temperature of $100{ }^{\circ} \mathrm{C}$, and $\mathrm{NO}_{2}$ fumes were given off. Heating continued until a clear solution was obtained, indicating that digestion was complete. The conical flask was then allowed to cool; the clear solution was transferred into a measuring cylinder and made up to $50 \mathrm{ml}$ with distilled water. The digested sample was then transferred into digestion bottles and subsequently labelled. The same method with little variation was followed for soil digestion.

\section{Proximate composition of snail tissues and chemical analysis of snail tissue and soil samples}

Methods of AOAC, 1990 and 2005 were adopted for moisture, crude fibre, protein, fat, ash, carbohydrate and nitrogen analyses, while lead, cadmium, mercury, zinc, nickel, magnesium, manganese, copper and calcium were analysed using Varian AA240 Atomic Absorption Spectrophotometer according to the methods of AOAC, 1990 and 2005.

\section{Calculation of bioaccumulation factors}

Data obtained from heavy metal analyses of the snail tissues and the surrounding soil were used to calculate the bioaccumulation factor. The concentration of each heavy metal in the land snail tissue per its concentration in the soil surrounding the tissue (bioaccumulation factor (BAF)) was calculated following the Dobrowolski and Skowronska (2002):

$$
\mathrm{BAF}=\frac{\text { Concentration in tissue }}{\text { Concentration in soil }}
$$

\section{Statistical analysis}

Data were analysed using R version 4.0.2 (R Core Team, 2020). Proximate composition of the snail was compared between species using univariate one-way analysis of variance (ANOVA) and post hoc Tukey HSD test. Heavy metal contents were compared using the Kruskal-Wallis
$\mathrm{H}$ test. Values are presented as mean \pm standard deviation (SD) and median (interquartile range, IQR). Level of significance was set at $p<0.05$.

\section{Results}

\section{Proximate composition}

The analysis of the proximate composition of the sampled Achatina spp recorded the presence of moisture, protein, crude fibre, fat and oil, ash, carbohydrates, nitrogen and calcium as summarised in Table 1. Proximate composition of the snails was similar for all parameters except calcium. Calcium was significantly higher in A. achatina $\left(\mathrm{F}_{2,42}=3.568, p=0.037\right)$; this arose mainly from the difference between $A$. achatina and $A$. marginata.

\section{Bioaccumulation factors of heavy metals}

The bioaccumulation factors of heavy metal contents in snails were generally low. All eight metals investigated were below the recommended tolerable limits according to WHO standard (Table 2). However, Achatina fulica recorded the highest bioaccumulation factor in metals such as $\mathrm{Cd}, \mathrm{Hg}, \mathrm{Zn}$ and $\mathrm{Cu}$; Achatina achatina recorded higher bioaccumulation factor in metals such as $\mathrm{Pb}$ and $\mathrm{Ni}$ than $A$. fulica but lesser than $A$. marginata, while Achatina marginata recorded highest bioaccumulation factor in $\mathrm{Mg}$ and $\mathrm{Mn}$.

The result of further analysis to compare the bioaccumulation of heavy metal composition at the community levels is presented in Figs. 1, 2, 3, 4, 5, 6, 7, 8. Lead, $\mathrm{Ni}$ and $\mathrm{Mn}$ contents of snails were similar between the five communities sampled ( $\mathrm{p}>0.05$ ) (Figs. 1, 2, 3). Magnesium contents at the community level was significant different $\left(\chi^{2}=11.923, \mathrm{df}=4, p=0.0179\right)$; snails from Agamede and Amede had the highest Mg contents (Fig. 4). Mercury contents of the snails showed wide withincommunity variation except at Mgbuji. The disparity in $\mathrm{Hg}$ composition was significant between community, Ebor and Mgbuji being the tops $\left(\chi^{2}=19.895, \mathrm{df}=4\right.$, $p=0.0005)$ (Fig. 5). $\mathrm{Cu}\left(\mathrm{x}^{2}=16.325, \mathrm{df}=4, p=0.0026\right)$ and $\mathrm{Cd}\left(\mathrm{X}^{2}=17.892, \mathrm{df}=4, p=0.0013\right)$ contents in snails were significantly different between the five communities (Figs. 5, 6, 7). Zn contents were not different at community level (Fig. 8).

\section{Discussion}

Mineral nutrients both macro and micro are needed for assessing the nutritional adequacy of diets for optimal growth and development of infants and children, for the protection of the health of pregnant and lactating women and for planning food policies for maintenance of health of other groups of both sexes (Nielsen, 2002). Minerals are known to play important roles in the maintenance of various biochemical activities in the 
Table 1 Proximate composition of Achatina species collected from some rural agro-settlements, south-east Nigeria

\begin{tabular}{|c|c|c|c|c|c|}
\hline Parameters & Species & Mean \pm SD & Median (IQR) & ANOVA $(\mathrm{df}=2,42)$ & $\Delta$ Mean $^{\neq}$ \\
\hline \multirow[t]{3}{*}{ Moisture } & Achatina achatina & $73.72 \pm 3.28$ & $72.50(2.04)$ & $F=0.075$ & - \\
\hline & Achatina marginata & $73.65 \pm 2.43$ & $73.05(2.43)$ & $p=0.928$ & \\
\hline & Achatina fulica & $73.37 \pm 1.91$ & $73.02(2.38)$ & & \\
\hline \multirow[t]{3}{*}{ Protein } & Achatina achatina & $20.03 \pm 3.50$ & $21.25(6.02)$ & $F=0.648$ & - \\
\hline & Achatina marginata & $18.83 \pm 2.65$ & $18.46(3.04)$ & $p=0.528$ & \\
\hline & Achatina fulica & $19.49 \pm 2.41$ & $19.33(3.42)$ & & \\
\hline \multirow[t]{3}{*}{ Crude fibre } & Achatina achatina & $0.63 \pm 0.57$ & $0.44(0.14)$ & $F=1.267$ & - \\
\hline & Achatina marginata & $0.36 \pm 0.49$ & $0.20(0.22)$ & $p=0.292$ & \\
\hline & Achatina fulica & $0.42 \pm 0.42$ & $0.30(0.85)$ & & \\
\hline \multirow[t]{3}{*}{ Fat and oil } & Achatina achatina & $3.85 \pm 1.09$ & $4.0(1.84)$ & $F=0.754$ & - \\
\hline & Achatina marginata & $4.40 \pm 2.37$ & $3.6(1.81)$ & $p=0.477$ & \\
\hline & Achatina fulica & $4.63 \pm 1.62$ & $4.2(2.24)$ & & \\
\hline \multirow[t]{3}{*}{ Ash } & Achatina achatina & $3.47 \pm 1.14$ & $3.56(1.68)$ & $F=1.205$ & - \\
\hline & Achatina marginata & $2.90 \pm 1.05$ & $3.24(1.67)$ & $p=0.310$ & \\
\hline & Achatina fulica & $2.98 \pm 1.06$ & $3.52(1.82)$ & & \\
\hline \multirow[t]{3}{*}{ Cho } & Achatina achatina & $4.42 \pm 1.66$ & $4.37(2.22)$ & $F=3.000$ & - \\
\hline & Achatina marginata & $6.13 \pm 2.68$ & $5.58(1.40)$ & $p=0.061$ & \\
\hline & Achatina fulica & $6.00 \pm 1.93$ & $5.69(2.35)$ & & \\
\hline \multirow[t]{3}{*}{ Nit } & Achatina achatina & $4.34 \pm 1.17$ & $4.50(1.84)$ & $F=0.108$ & \\
\hline & Achatina marginata & $4.15 \pm 1.06$ & $4.60(1.69)$ & $p=0.898$ & - \\
\hline & Achatina fulica & $4.26 \pm 1.06$ & $4.74(1.72)$ & & \\
\hline \multirow[t]{3}{*}{$\mathrm{Ca}$} & Achatina achatina & $0.22 \pm 0.03$ & $0.22(0.04)$ & $F=3.568$ & $\mathrm{AM}-\mathrm{AA}=-0.023^{*}$ \\
\hline & Achatina marginata & $0.20 \pm 0.03$ & $0.20(0.04)$ & $p=0.037^{*}$ & $A F-A A=-0.017$ \\
\hline & Achatina fulica & $0.20 \pm 0.02$ & $0.20(0.03)$ & & $A F-A M=0.006$ \\
\hline
\end{tabular}

$S D$ standard deviation, IQR interquartile range, ANOVA one-way analysis of variance, AM Achatina marginata, AA Achatina achatina, AF Achatina fulica

${ }^{\ddagger}$ TukeyHSD post hoc test mean difference and $p$ value, provided only where ANOVA was significant

$P$ significant at ${ }^{*} p<0.05,{ }^{* *} p<0.01,{ }^{* * *} p<0.001$

biological systems (Pearson \& Gillet, 1999). Assessment of the level of heavy metals in any environment gives information on the toxicity level and level of ecological friendliness, which by implication dictates the safe level of most components of the environment.

Molluscs serve as a significant and essential cheap source of daily protein diet in Nigeria (Ademolu et al., 2004). The high moisture content observed could be that sampling was conducted when raining season has not terminated. The moisture content of food is of great importance to food processor because a number of biochemical reactions and physiological changes in food depend much on the moisture content. Further, it exhibits a great effect on stability and quality of foods. It has been reported that snail meat is found to be rich in protein, is low in lipid and contains essential minerals like zinc, iron, calcium and magnesium (Ademolu et al., 2004). However, the high crude protein content observed in the study could be attributed to the litter and vegetative contents which the snails feed on.
The low lipid content of snail has been reported (Ademolu et al., 2004). This quality makes snail meat good for some groups of people suffering from lipid-related diseases. The relatively high values of ash content recorded in our study imply rational quantity of mineral elements for building a healthy body and proper functioning of body tissues because ash content is a measure of the total amount of mineral present within a given sample of food (Nielsen, 2002).

Nitrogen and calcium levels recorded in our study are at variance with the results of Babalola and Akinsoyinu, (2009). The levels of nitrogen and calcium observed could be attributed to the food the snails feed on. Calcium provides rigidity to the skeleton and blood clotting and plays most metabolic processes (WHO \& FAO, 2004).

Our findings on crude fibre and carbohydrate disagree and agree with the findings of Ademolu et al. (2004). However, we sampled from rural agro-settlements, but they farmed and feed with a selected meal. Low crude fibre content can be attributed to a decrease 
Table 2 Bioaccumulation factors of heavy metals Achatina achatina, Achatina marginata and Achatina fulica

\begin{tabular}{|c|c|c|c|c|}
\hline Metal (ppm) & Achatina achatina & Achatina marginate & Achatina fulica & Standard* \\
\hline \multicolumn{5}{|l|}{$\mathrm{Pb}$} \\
\hline Mean $\pm S D$ & $0.0007 \pm 0.003$ & $0.003 \pm 0.005$ & $0.0002 \pm 0.005$ & 0.01 \\
\hline Median (IQR) & $0(0)$ & $0(0.003)$ & $0(0)$ & \\
\hline \multicolumn{5}{|l|}{$\mathrm{Cd}$} \\
\hline Mean \pm SD & $0.001 \pm 0.002$ & $0.0003 \pm 0.0006$ & $0.002 \pm 0.001$ & 0.03 \\
\hline Median (IQR) & $0.001(0.002)$ & $0.00(0)$ & $0.002(0.002)$ & \\
\hline \multicolumn{5}{|l|}{$\mathrm{Hg}$} \\
\hline Mean \pm SD & $0.002 \pm 0.007$ & $0.026 \pm 0.014$ & $0.032 \pm 0.016$ & \\
\hline Median (IQR) & $0.022(0.010)$ & $0.024(0.020)$ & $0.034(0.010)$ & \\
\hline \multicolumn{5}{|l|}{$\mathrm{Zn}$} \\
\hline Mean \pm SD & $0.006 \pm 0.006$ & $0.002 \pm 0.003$ & $0.008 \pm 0.006$ & 3.00 \\
\hline Median (IQR) & $0.003(0.010)$ & $0(0.001)$ & $0.010(0.010)$ & \\
\hline \multicolumn{5}{|l|}{$\mathrm{Ni}$} \\
\hline Mean $\pm S D$ & $0.014 \pm 0.013$ & $0.016 \pm 0.020$ & $0.009 \pm 0.008$ & \\
\hline Median (IQR) & $0.01(0.019)$ & $0.01(0.025)$ & $0.01(0.015)$ & \\
\hline \multicolumn{5}{|l|}{$\mathrm{Mg}$} \\
\hline Mean \pm SD & $0.075 \pm 0.061$ & $0.112 \pm 0.058$ & $0.097 \pm 0.062$ & 20.0 \\
\hline Median (IQR) & $0.10(0.09)$ & $0.13(0.07)$ & $0.12(0.11)$ & \\
\hline \multicolumn{5}{|l|}{$M n$} \\
\hline Mean \pm SD & $0.0001 \pm 0.0004$ & $0.0004 \pm 0.0006$ & $0.0001 \pm 0.0004$ & 0.20 \\
\hline Median (IQR) & $0(0)$ & $0(0.001)$ & $0(0)$ & \\
\hline \multicolumn{5}{|l|}{$\mathrm{Cu}$} \\
\hline Mean \pm SD & $0.01 \pm 0.009$ & $0.013 \pm 0.009$ & $0.015 \pm 0.012$ & 2.00 \\
\hline Median (IQR) & $0.01(0.01)$ & $0.01(0.01)$ & $0.01(0.02)$ & \\
\hline
\end{tabular}

*WHO recommended standard

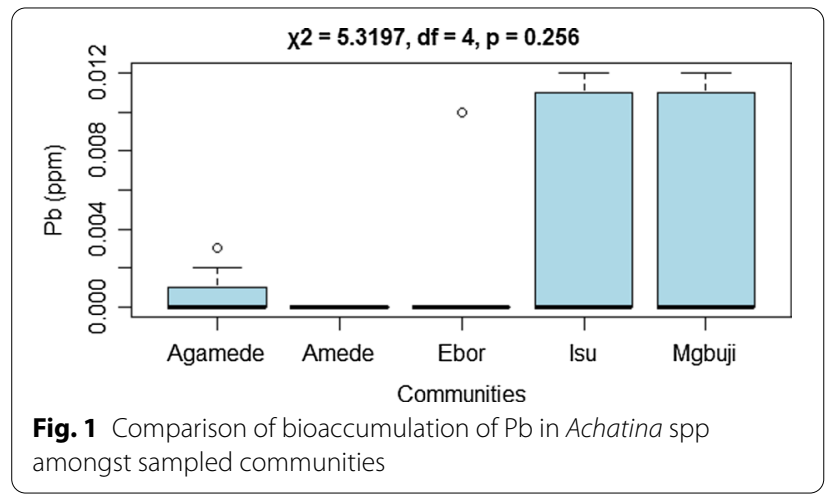

in microbiological metabolism of lingo polysaccharide or due to non-utilisation of the sugar during metabolic activities leaving a lower or no fibre content (Oshodi \& Ekperigin, 1987). The low carbohydrate values recorded by implication makes snail meat to be recognised as a low carbohydrate diet.

Snails contribute a lot to ecotoxicology because they feed litter and dead animals, which encourages bioaccumulation of pollutants, especially heavy metals in their tissues leading to transfer of pollutants to other

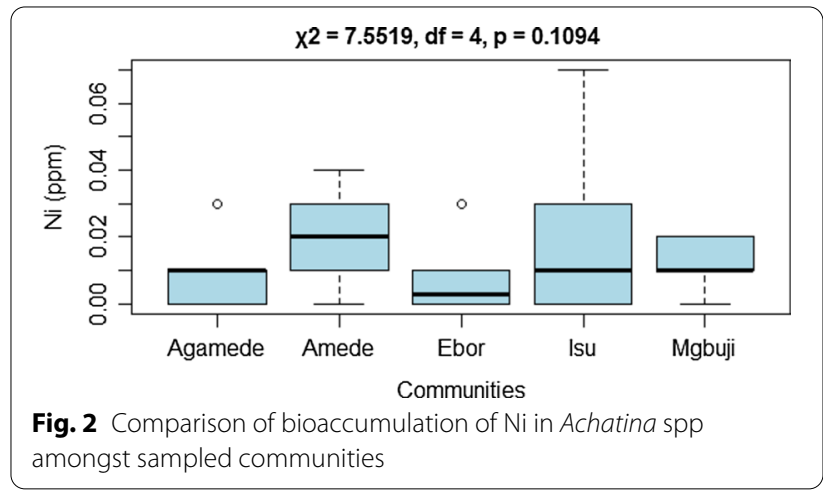

organisms that feed on snails (Manu et al., 2008). However, the chemical analysis carried out in this study showed that all metals detected were within WHO below recommended tolerable limits. Copat et al. (2013) reported that accumulation of heavy metals snail tissues is in proportion to the degree of environmental contamination, and this makes snail good bioindicators of ecotoxicology.

The bioaccumulation factors of heavy metal contents in snails sampled in our study area were generally low within 


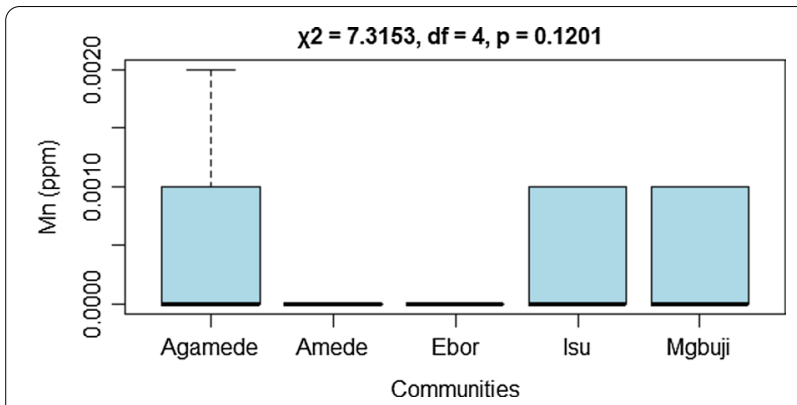

Fig. 3 Comparison of bioaccumulation of $\mathrm{Mn}$ in Achatina spp amongst sampled communities

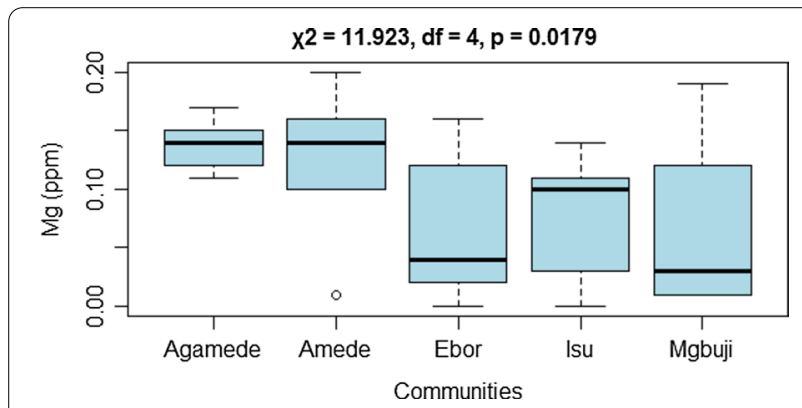

Fig. 4 Comparison of bioaccumulation of $\mathrm{Mg}$ in Achatina spp amongst sampled communities
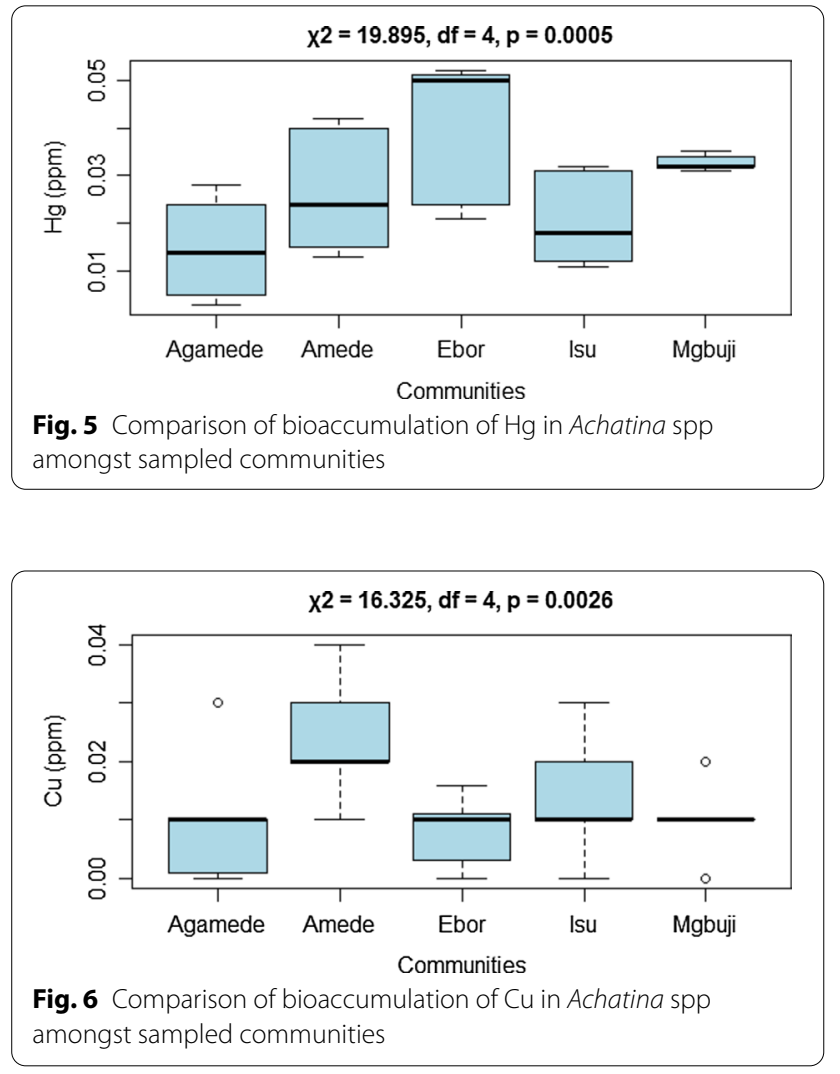
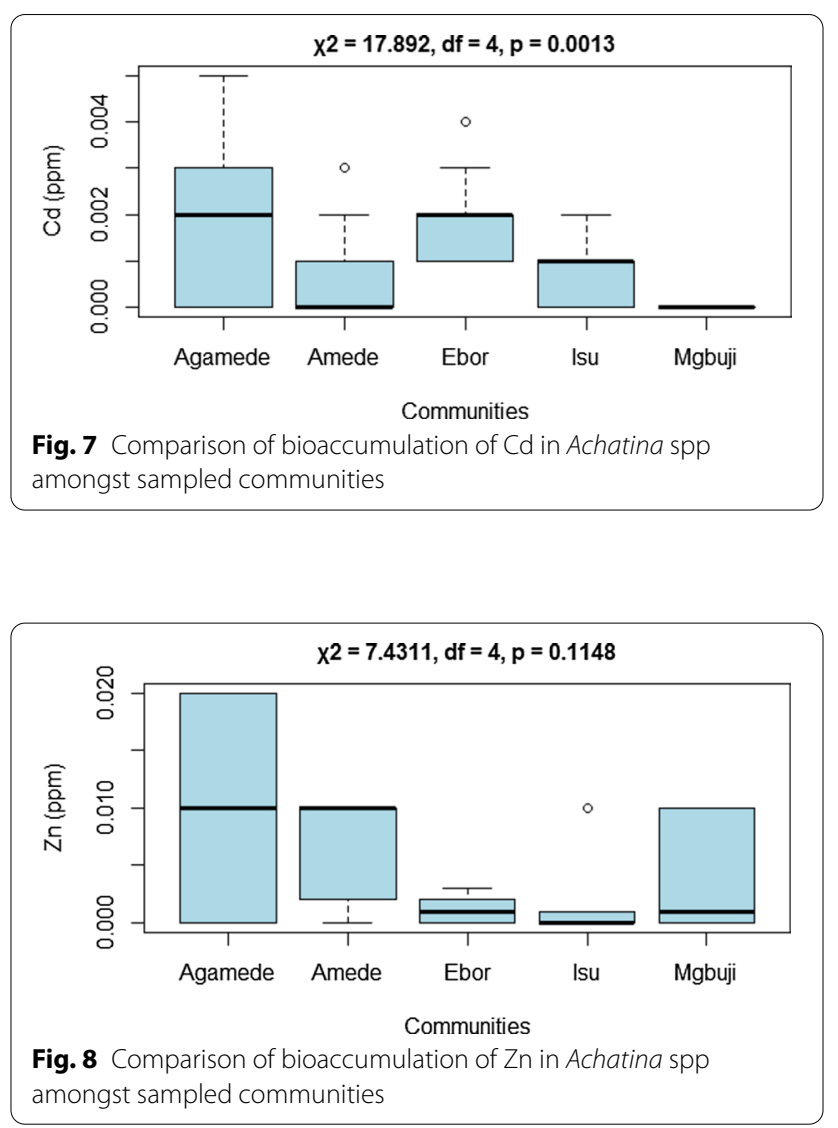

the World Health Organization-recommended limits. This implies that land snails in our study area were safe for consumption. However, further analysis to compare the bioaccumulation of heavy metal composition at community levels revealed that some Achatina spp recorded relatively high levels of metals as compared with others. Achatina fulica recorded the highest bioaccumulation factor in $\mathrm{Cd}, \mathrm{Hg}, \mathrm{Zn}$ and $\mathrm{Cu} ; A$. achatina recorded higher bioaccumulation factor in metals such as $\mathrm{Pb}$ and $\mathrm{Ni}$ than A. fulica but lesser than A. marginate, while A. marginata recorded the highest bioaccumulation factor in $\mathrm{Mg}$ and $\mathrm{Mn}$. Our findings show that $\mathrm{Hg}$ and $\mathrm{Pb}$ consonants and $\mathrm{Cd}$ vary with Eneji et al., 2016. Zinc and Cu levels disagree with the report of Ezemonye and Ilechie (2010). The report of Iwegbue et al. (2008) agrees with $\mathrm{Ni}$ level in our study but disagrees with Mn level. Conversely, an attempt to link the relatively high level of metals recorded in species with sampling location showed that some metals $(\mathrm{Ni}$, $\mathrm{Mn}, \mathrm{Pb}$ and $\mathrm{Zn}$ ) had no significant difference with regard to location. Otitoloju et al. (2009) reported low penetrative ability of metals in exposed organisms. Some metals were significantly higher at some locations such as Agamede $(\mathrm{Cd})$, Amede $(\mathrm{Cu}, \mathrm{Mg})$ and Ebor $(\mathrm{Hg})$. The discrepancy in the level of metals per location could be as result of the 
difference in human activities (such as fertiliser application, application of pesticides and similar activities) and effect of long-range transboundary air pollution (WHO, 2007).

\section{Conclusion}

Analysis of the proximate composition of the rural agrosettlements, south-east Nigeria sampled Achatina spp, indicated the presence of many nutrients and could serve as an alternative source of nutrients to rural dwelling communities. The bioaccumulation factors of heavy metal contents in snails were generally low and were below recommended tolerable limits according to the WHO standard. This implies that the snails were safe for consumption. However, the presence of $\mathrm{Cd}, \mathrm{Hg}$ and $\mathrm{Pb}$ in snails' tissues implies that human activities that release these heavy metals into the environment should be put in check.

\section{Acknowledgements}

Authors appreciate all laboratory assistants and the zoo attendants at the zoological garden, University of Nigeria, Nsukka, for their contributions during this study.

\section{Authors' contributions}

EIN provided all the materials used for this study. EIN handled the sampling. EIN, GEO, IOA and CDN designed this research. All authors were involved for sampling, field work, laboratory activities, data collection and statistical analysis. The manuscript was prepared by EIN and CDN, while all authors edited it. The final version was read and approved by all authors. All authors read and approved the final manuscript.

\section{Funding}

This research was funded by Dr. Emmanuel Ikechukwu Nnamonu. There was no external sponsorship.

\section{Availability of data and materials}

We declare that data generated from this study are readily available as well as information about material used.

\section{Declarations}

\section{Ethics approval and consent to participate}

The ethical conditions Concerning Animal Research Outside the Laboratory as stated by Nisbet and Paul (2004) were strictly observed in this research.

\section{Consent for publication}

Not applicable.

\section{Competing interests}

Authors declare that there is no conflict of interest among authors.

\section{Author details}

'Department of Biology, Federal College of Education, Eha-Amufu, Enugu State, Nigeria. ${ }^{2}$ Department of Zoology and Environmental Biology, University of Nigeria, Nsukka, Enugu State, Nigeria.

Received: 9 June 2021 Accepted: 4 November 2021

Published online: 21 November 2021

\section{References}

Ademolu, K. O., Idowu, A. B., Mafiana, C. F., \& Osinowo, O. A. (2004). Performance, proximate and mineral analyses of African giant land snail
(Archachatina marginata) fed different nitrogen sources. African Journal of Biotechnology, 3(8), 412-417.

Association of Official Analytical Chemistry (1990). Official methods of analysis, 15th Edn. Washington DC.

Association of Official Analytical Chemistry (2005). Official methods of analysis of the Association of Official Analytical Chemists, 17th Ed., AOAC, Gathersburg, MD., USA, p. 18

Babalola, O. O., \& Akinsoyinu, A. O. (2009). Proximate composition and mineral profile of snail meat from different breeds of Land Snail in Nigeria. Pakistan Journal of Nutrition, 8, 1842-1844.

Centre for Disease Control (1991). Preventing lead poisoning in children. Atlanta, GA, Centers for Disease Control and Prevention.

Copat, C., Giovani, A., Maria, F., Caterina, L., Roberto, F., Salvatore, S., \& Margherita, F. (2013). Heavy metals concentrations in fish and shellfish from eastern Mediterranean Sea. Consumption Advisories. Food and Chemical Toxicology, 53, 33-37.

Dobrowolski, R., \& Skowrońska, M. (2002). Concentration and discrimination of selected trace metals by freshwater mollusks. Bull Environmental Contamination and Toxicology, 69, 509-515.

Ebenebe, C. I. (2000). Mini-livestock production in Nigeria. The present and future. In Proceedings of 5 th annual conference of animal science association in Nigeria, Port Harcourt, Nigeria, September 19-22.

Eneji, I. S., Wuana, R. A., \& Akpan, U. J. (2016). Trace metals levels in African Giant Land Snails (Achatina achatina) from Selected Local Government Areas in Akwa Ibom State, Nigeria. Open Access Library Journal, 3, e2244. https://doi.org/10.4236/oalib.1102244

Ezemonye, L. \& llechie, I. (2010). Bioaccumulation of heavy metals in freshwater snail. African World Press ISBN 1-59221-169-0, pp. 91-112.

Herbert, D. \& Kilburn, D. (2004). Field guide to the land snail and slugs of Eastern South Africa. Natal Museum, Pietermaritzburg, South Africa. https://hdl.handle.net/10520/EJC17937

Houndonougbo, M. F., Chrysostome, C. A. A. M., Odoulami, R. C., \& Codjia, J. T. C. (2012). Snail shell as an efficient mineral feedstuff for layer hens: Effects and optimum rate. Livestock Research for Rural Development, 24(9), $1-7$.

Iwegbue, C. M. A., Arimoro, F. O., Nwajei, G. E., \& Eguavoen, O. (2008). Heavy metal content in the african giant snail archachatina marginata (swainson, 1821) (gastropoda: Pulmonata: Achatinidae) In southern nigeria. Folia Malacological, 16(1), 31-34.

Lange, C. N., \& Mwinzi, M. (2003). Snail diversity, abundance and distribution in Arabuko Sokoke forest, Kenya. African Journal of Ecology, 41, 61-67.

Manu, A., Bala, K., Shweta, R., Achal, R., Barinder, K., \& Neeray, M. (2008). Heavy metal accumulation in vegetables irrigated with wastes from different sources. Food Chemistry, 111(4), 811-815.

Nielsen, S. S. (2002). Introduction to the chemical analysis of foods, 1sted. CBS Publishers and Distributors India, 233.

Nisbet, I. C. T., \& Paul, E. (2004). Ehtical issues concerning animal research outside the laboratory. Institute for Laboratory Animal Research Journal, 45(3), 375-377.

Nnamonu, E. I., Nkitnam, E. E., Ugwu, F. J., Ejilibe, O. C., Ezenwosu, S. U., \& Ogbodo, G. U. (2018). Physicochemical assessment of vulnerability of the River Ebenyi in Eha-Amufu and Environs, Southeast Nigeria. Annual Research and Review in Biology, $27,1-9$.

Nnamonu, E. I., Ugwu, F. J., Ejilibe, O. C., Ani, O. C., Martins, P. E., Onyeidu, S. O., \& Onyeidu, B. U. (2019). Assessment of bacteriological quality of water sources from an agrarian settlement in South-East Nigeria. African Journal of Microbial Research, 13(30), 675-682.

Oshodi, A. A., \& Ekperigin, M. M. (1987). Functional Properties of Pigeon Pea. (Cajanus cajan) Flour. Food Chemistry, 34, 187-191.

Otitoloju, A. A., Ajikobi, D. O., \& Egonmwan, R. I. (2009). Histopathology and bioaccumulation of heavy metals (Cu \& Pb) in the giant land snail, Archachatina marginata (Swainson). The Open Environmental Pollution Toxicology Journal, 1, 79-88.

Pearson, A. M. \& Gillet, T. A. (1999). Processed meats. Gaithersburg, Md. Aspen. Springer.

Rusan, M. J. M., Hinnawi, S., \& Rousan, L. (2007). Long term effect of wastewater irrigation of forage crops on soil and plant quality parameters. Desalination, 215(1/3), 143-152.

Uboh, F. E., Williams, I. O., \& Essien, N. C. (2014). Effect of processing on the proximate and mineral composition of Archachatina marginata and Achatina achatina. Food and Public Health, 4(1), 10-14. 
Whitfield, J. (2001). Vital signs. Nature, 411, 989-990.

WHO \& FAO (2004). Vitamin and mineral requirements in human nutrition, Second edition.

WHO (2007). Health risks of heavy metals from long-range transboundary air pollution.

\section{Publisher's Note}

Springer Nature remains neutral with regard to jurisdictional claims in published maps and institutional affiliations.
Submit your manuscript to a SpringerOpen ${ }^{\odot}$ journal and benefit from:

- Convenient online submission

- Rigorous peer review

- Open access: articles freely available online

- High visibility within the field

- Retaining the copyright to your article

Submit your next manuscript at $\boldsymbol{\nabla}$ springeropen.com 